\title{
Environmental Change in Agricultural Land in Southwest Côte d'Ivoire: Driving Forces and Impacts
}

\author{
A. Y. N'go ${ }^{1 *}$, J. T. Ama-Abina ${ }^{1}$, A. Z. Kouadio ${ }^{2}$, H. K. Kouassi ${ }^{1}$, I. Savané ${ }^{1}$ \\ ${ }^{1}$ Nangui Abrogoua University, Environmental and Geosciences Laboratory, Côte d'Ivoire; ${ }^{2}$ Jean Lorougnon Guede University of \\ Daloa, Côte d'Ivoire. \\ Email: "nyaoalexis@yahoo.fr
}

Received August $28^{\text {th }}, 2013$; revised September $27^{\text {th }}, 2013$; accepted October $25^{\text {th }}, 2013$

Copyright (C) 2013 A. Y. N'go et al. This is an open access article distributed under the Creative Commons Attribution License, which permits unrestricted use, distribution, and reproduction in any medium, provided the original work is properly cited. In accordance of the Creative Commons Attribution License all Copyrights (C) 2013 are reserved for SCIRP and the owner of the intellectual property A. Y. N'go et al. All Copyright (C) 2013 are guarded by law and by SCIRP as a guardian.

\begin{abstract}
Environmental conditions change in the Southwest of Côte d'Ivoire has been a major issue in development debates over the last decades. Using remote sensing based on land cover change analysis, climatic data, national statistical data, we analyzed the drivers of environmental change in Southwestern of Côte d'Ivoire. Being part of the perennial crops basin, Southwestern of Côte d'Ivoire has witnessed rapid degradation of environmental conditions caused by the conversion of forest areas to agricultural land during the last 20 - 30 years and by a combination of decline in precipitation, soil degradation, a diversity of policies with little concern for the environment and population pressure. We concluded that while climate variability has influenced environmental change in the area of Sassandra, various types of anthropogenic and State interventions in agriculture appear to have been the main underlying causes of environmental degradation.
\end{abstract}

Keywords: Land Use; Climate Variability; Environmental Change; Population Pressure; Sassandra; Côte d'Ivoire

\section{Introduction}

Côte d'Ivoire is located in the intertropical zone, with about $60 \%$ of the population living in rural areas and the largest share of GDP (Gross Domestic Product) coming from natural resources extraction. The natural vegetation is constituted by important forest cover in south and savanna in the north. Nowadays, the performance of the Ivorian economy is largely based on agriculture which contributes about one third of GDP and employs more than $60 \%$ of the population [1]. The sector also provides about two-thirds of export earnings. A significant change in crops production could thereby have a direct impact on the economy. Although the importance of agriculture in the national socio-economic development is recognized, forests and soils of Côte d'Ivoire remain very assaulted mainly because of cultural practices. Land cover change due to human activities is currently proceeding more quickly in developing countries than in the developed World, and affected strongly the surface temperature [2].

Moreover, since 1970's, there was a period of defi-

${ }^{*}$ Corresponding author. cient rainfall called dry season. The appearance of a few surplus at the end of the 2000s years, did not allow us to confirm the actual return to the wet period in Gulf of Guinea region. Studies of Mahé and L'Hôte [3,4] that attempted to provide answers to these uncertainties were limited to the Sahel region. In fact, rainfall trends and variability affect directly or indirectly other variables, such as rained crop productivity, vegetation and soil degradation process, reduction in the quality and quantity of the ecosystem services, human livelihoods, etc. [5-7].

Furthermore, in terms of agro-economic loss of the forest, ecosystem causes an obstacle of a structural nature of Ivorian agricultural system [8]. Generally, it has been demonstrated that anthropogenic causes of ecosystem change, such overexploitation of natural resources, are determined by population growth, demographic shifts, economic and technological development, cultural forces, values and beliefs, institutions and governance structures as well as the interactions among all these underlying driving factors [9]. The southwestern of Côte d'Ivoire, new agricultural belt, seems to be particularly affected, with exceptional anthropogenic pressure source of land 
degradation, declining productivity and various land disputes. Indeed, increasing population in developing cities has caused rapid changes in land cover and increased environmental degradation. So Geographic Information System (GIS) and remote sensing (RS) techniques are powerful and cost-effective tools for assessing the spatial and temporal dynamics and changes in land cover and land use [10].

Generally, success in natural resources management depends on precise diagnosis of the state and evolution of the resources, but also on a clear identification of active agents and driving forces that sustain negative trend in resource availability or access. This work aims at examining the data space, climate and population to understand the interaction and impact of climate risks and migration on the dwindling agricultural production support that-is-to say forest lands.

\section{Study Area}

The study area is located in the southwest of Côte d'Ivoire in a transitional zone between equatorial and tropical climates (Figure 1).

The studied area is part of eco-geographical zone, called the Sassandra south basin. Average annual rainfall

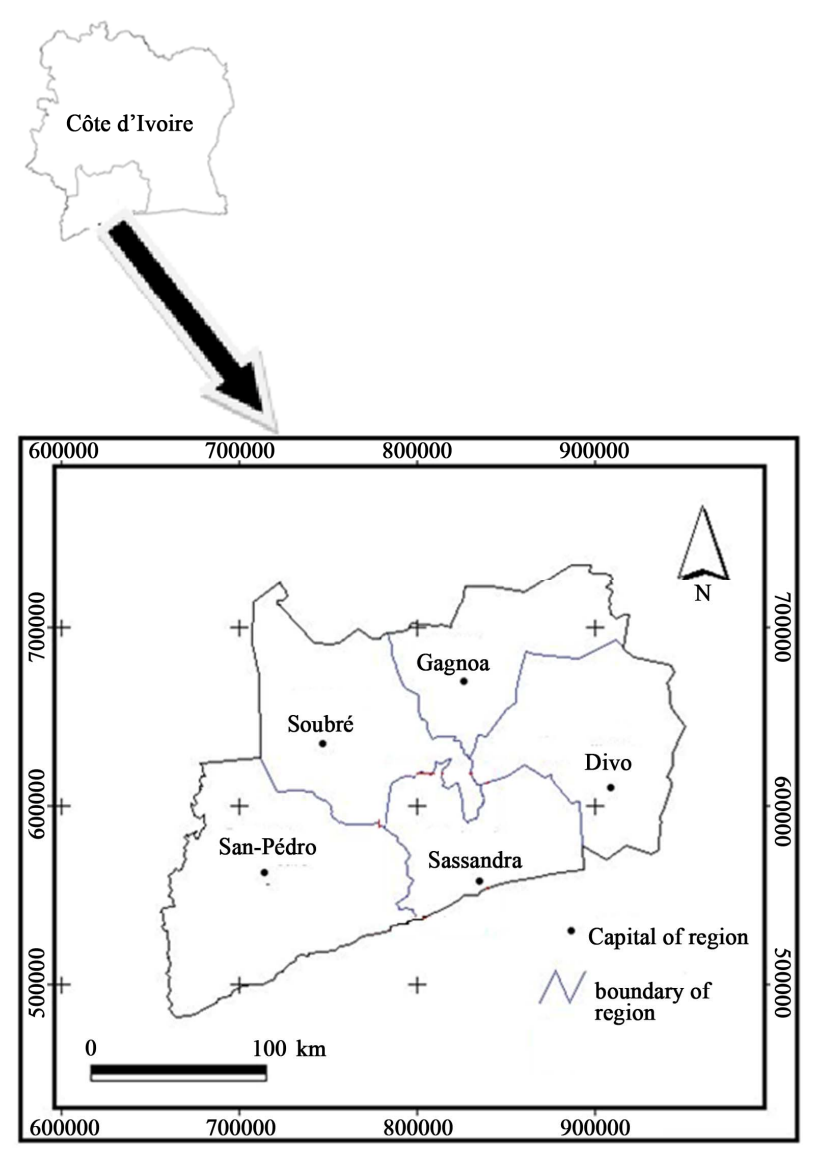

Figure 1. Location of the study area. is about $1500 \mathrm{~mm} /$ year and a temperature between $25^{\circ} \mathrm{C}$ and $27^{\circ} \mathrm{C}$. The land cover of the area includes various vegetation types [11] such as: swamp forests, dense evergreen forest on soil with high water retention capacity, of the mangrove soil hydromorphic gley and dense evergreen forest. The soils are ferrallitic types heavily unsatured and are characterized by the presence of thin topsoil and a gravelly underdeveloped horizon. They compensate for their poverty by good chemical and physical property by a sharp deterioration in wet weather. The relief is quite contrasting with the West consists of high peaks and other parts mainly composed of plains.

\section{Data and Methodology}

\subsection{Data}

The data used in this work are three types: climatic data, satellite data (satellite image) and demographics. Climate data (rainfall and evapotranspiration) are derived from Gagnoa and Sassandra agro-climatological stations. These stations belong to the network measurement of the Direction of National Meteorology of Côte d'Ivoire. These stations, respectively center west and southwest of Côte d'Ivoire, were chosen because they have long series (at least 30 years of observations) and exhibit a limited number of missing and erroneous values. The data cover the period from 1950 to 2000. In reporting data on forest dynamics, we treated the Landsat image of 1986 and 2001 based on knowledge of the terrain. Demographic data come from statistical yearbooks of the NSI (National Statistics Institute of Cote d'Ivoire) and include the General Census of Population and Housing in 1988 and 1998.

\subsection{Methodology}

Land use/cover mapping using Landsat ETM data of December 1986 and December 2001 has been conducted to derive the direction and the magnitude of change in part of the study area and to underline the importance of land degradation on natural resources loss in the area. After the visual interpretation, an unsupervised classification was undertaken. In fact, pixels were grouped on the basis of similar spectral signatures [12]. Then, a simple supervised classification (with field data) of the two images was carried out to map and identify in the extent of the four land use/cover classes based on known characteristics of the area in the initial grouping (water bodies, forest, culture/fallow, urban zone, uncovered soil). By specifying the spectral definition of each corresponding classification quality was appreciably improved. One of the principal advantages of utilizing satellite images in this analysis was the fact that it can uncover land-use and vegetation changes over time.

In order to analyze the pressure on forests and farm- 
land of the deficit, we coupled maps of the growth rate of rural population, the map of land use/cover and the map of slippage isohyet $1200 \mathrm{~mm}$ between 1970 and 2000 . Multivariate analysis was performed to highlight the determining factor (or rain forest) in increasing the rural population.

Climate risk faced by agricultural production has been analyzed through the method of Eldin [13] described by Brou [8] which is to assess, to some extent, the probability of occurrence of adverse climatic factors and likely to cause the partial or total loss of a crop. Follow the water supply of a crop is to compare two homogeneous quantities (same unit) expressing the needs on the one hand and secondly the availability. These two quantities were expressed by potential evapotranspiration (ETP) and by the rainfall (P) and soil water reserves (UK). Regional macroscopic approach adopted in this study allows us to consider the rain as the predominant term of the balance sheet and thus absorb water availability than precipitation. The question then is to compare the rainfall $(\mathrm{P})$ to evapotranspiration (ETP). This term water balance represents an upper bound of the water consumption of any crop at any time. Get a month of rain over the ETP is to be assured that plants are bound to water [13]. On this theoretical basis, we calculated over the period 19502000, the frequency (probabilistic approach) with monthly rainfall which meet or exceed the monthly values of the ETP. The choice of a probability (p), reflecting the risk of more or less complete loss of the crop due to water shortages, acceptable to the farmer, used to define the corresponding period of rainfed. In this work we have assumed that this probability is $\mathrm{p}=0.03[8,14,15]$, a partial loss or total accepted approximately one year to three.

\section{Results and Discussion}

\subsection{Directions of Change in Sassandra South Watershed}

The study is known for the considerable changes of its bio-physical environment during the last decades as noted by Brou [8]. In order to characterize the environment change that accompanied this development, we will first address the issues related to key driving forces and the consequences of environment change. This will include land use/land cover, rainfall and soil degradation. Second, we will discuss how social, political, economic and demographic parameters have shaped the environment of southwestern of Côte d'Ivoire today. Taken together, these discussions will serve to illustrate the coevolution of environmental and societal conditions.

\subsubsection{Land Cover and Land Use Dynamic}

Remote sensing data were analyzed to estimate land use and land cover changes (LUCC). A purpose of this investigation was to determine whether these land cover change resulted from change in land use. We chose five localities in this study area to highlight the dynamics land cover. A cross-table analysis was undertaken for the two time period (Table 1). This statistical examination revealed that all aspects of land covers were declined. By visually comparing the two images (Figure 2), it's possible to identify the obvious changes in the four classes (water, forest, culture/fallow, habitat/ bare soil) during the two times.

To highlight this dynamics we made areas of interest at the estuary of Sassandra and determined the evolution of the different land use rate. The map of land (Figure 3) following the classification of Landsat TM 1986 and ETM 2001 are classified into five themes chosen for the purpose of the study: 1) wetlands, 2) forest 3) water bodies, 4) crop areas and/or fallow and 5) habitats.

Land cover change between 1986 and 2001 were shown in Figure 4. The statistical examination revealed that only areas covered by water were relatively stable during the study period. Wetlands and forests are declining opposite habitats and fallows have sharply increased. This land cover change in southern Sassandra appears to be linked to agricultural expansion and degradation of the natural vegetation. Indeed, the forest in the southwestern of Côte d'Ivoire inexorably disappears in favor of Cocoa and coffee plantations and fallow. Moreover, the proliferation of habitats was the sign of the forest colonization by migrants

In fact, since the independence of Côte d'Ivoire in 1960, agricultural and other government policies have influenced the land cover dynamics in the country particulary southwest. The linkage between population growth and land degradation in the southwest of Côte d'Ivoire has been frequently debated. Causes are to be found in changing land use and land cover, which are expressions of human impact on the environment [16]. The catalyst for this process according to Ibo [17] was

Table 1. Land use/land cover for each time period (in pixels).

\begin{tabular}{cccc}
\hline \multicolumn{4}{c}{$\begin{array}{c}\text { land cover for each } \\
\text { time period en pixels }\end{array}$} \\
\hline Locality & $\mathbf{1 9 8 6}$ & $\mathbf{2 0 0 1}$ & $\begin{array}{c}\text { Average \% of change } \\
\mathbf{( 1 9 8 6 - 2 0 0 1 )}\end{array}$ \\
\hline Gréguigré & 457,568 & 263,778 & -42.35 \\
Grihiri & 332,553 & 320,622 & -3.59 \\
Baléko & 778,348 & 656,148 & -15.7 \\
Niapidou & 278,353 & 75,053 & -73.04 \\
Kokolopozo & 207,117 & $1,293,939$ & -37.43 \\
TOTAL & $\mathbf{2 , 0 5 3 , 9 3 9}$ & $\mathbf{2 , 6 0 9 , 5 4 0}$ & $\mathbf{- 3 4 . 4 2 2}$ \\
\hline
\end{tabular}




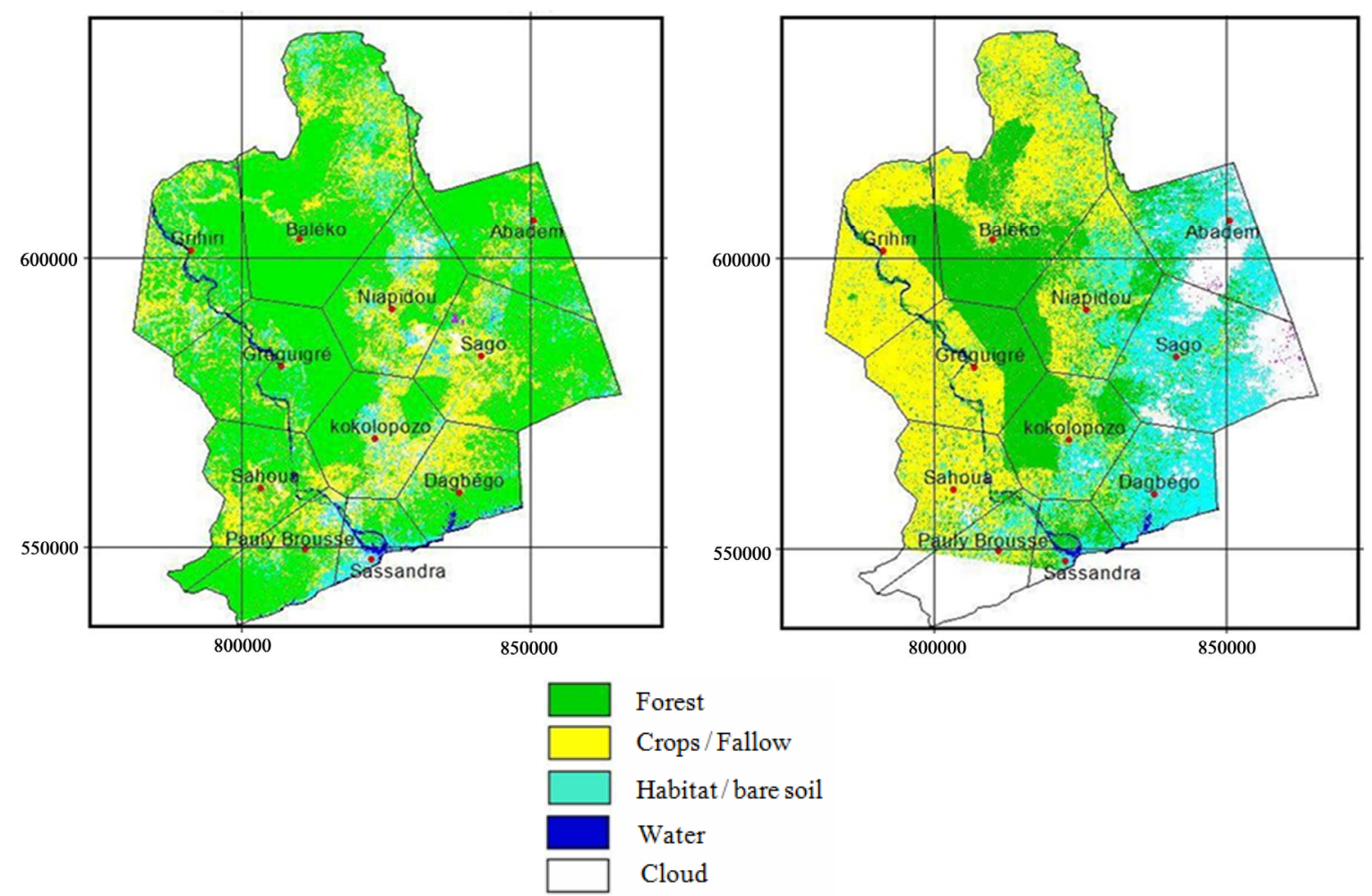

Figure 2. Dynamic of land cover to 1986 to 2001.
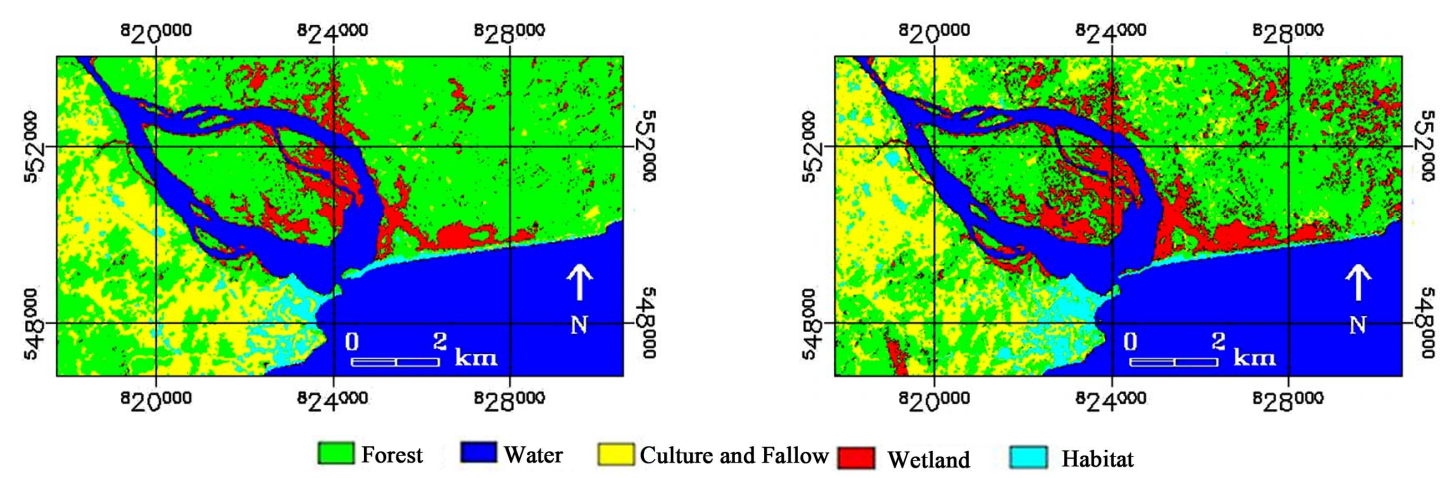

Figure 3. Land cover/land use in the Sassandra river estuary in 1986 and 2001.

the migration of populations from areas above the 8th parallel to the southern forest naturally rich but poor workmanship. This is why an analysis of the population dynamics is needed (Figure 5).

\subsubsection{Demography}

A comparative study of areas of heavy deforestation and land degradation in Sassandra region showed that the most affected area is the one that is subject to strong migration. The Figure 5 attests this hypothesis in Sassandra region. We see through this Figure that the Sassandra city presents a low evolution of its population while in rural the population grew exponentially. Although, population pressure may be an important reason behind agricultural expansion, it is, nevertheless, very complex to single it out as a main driving force [5]. Elsewhere, Mbow et al. [5] have showed that the widespread land degradation has often been accompanied by synchronous rural population growth. Generally it has been demonstrated that anthropogenic causes of ecosystem change, such as overexploitation of natural resource are determined by population growth, demographic shifts, economic and technological development, cultural forces values and beliefs, institutions and governance structures as well as the interactions among all these underlying driving factors $[9,18]$. Thus, this region is the result of these various interactions mentioned above. The sharp population growth in most of the village is associated with a high birth rate and migration [17].

This demographic development has not only posed 


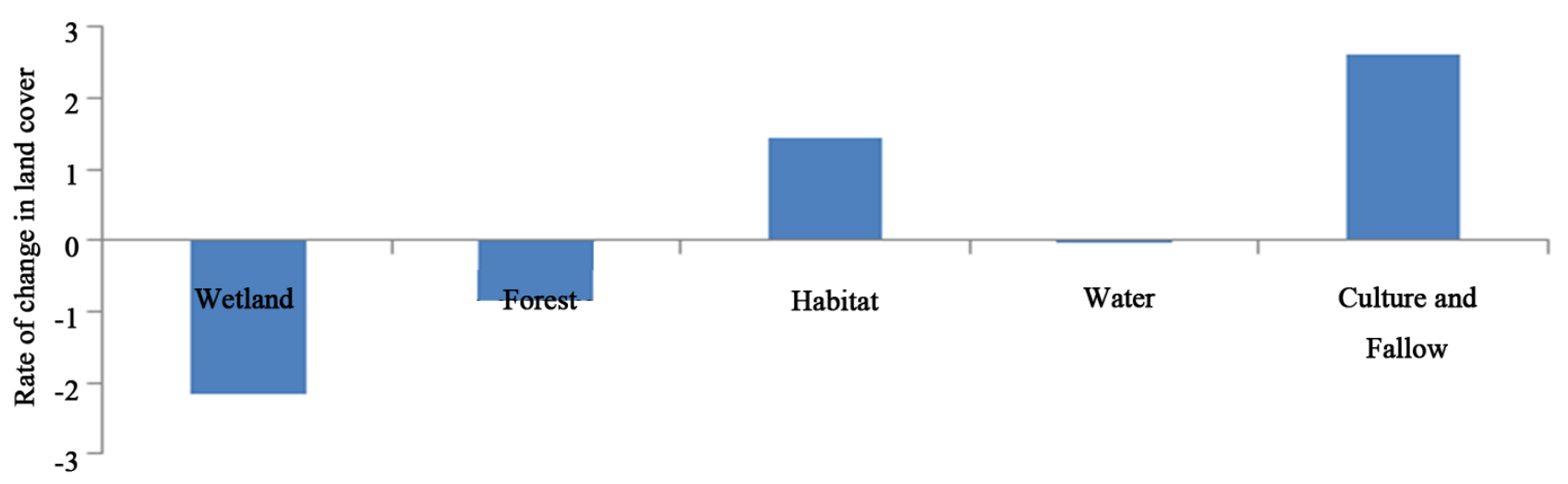

\section{Land cover}

Figure 4. Rate of change of land use in the estuarine area of Sassandra in 1986 and 2001.

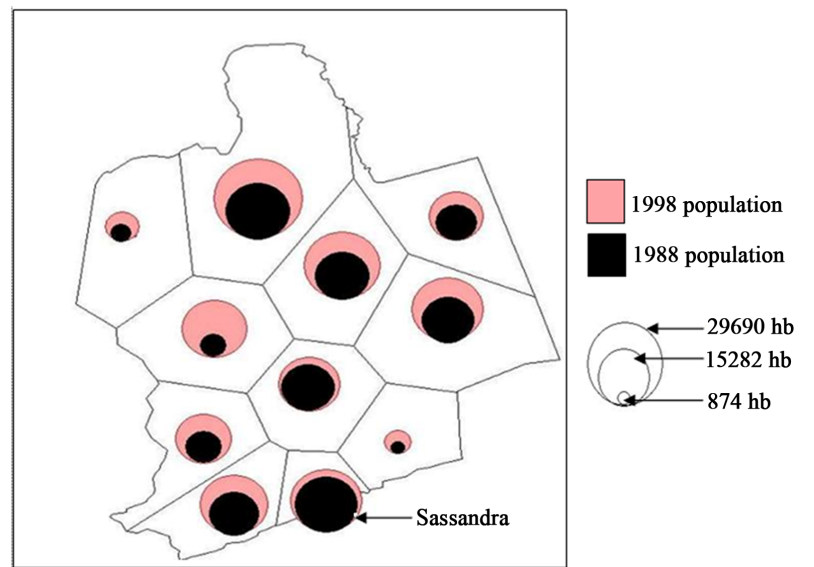

Figure 5. Rural population growth between 1986 and 2001 in Sassandra region.

security, economic, social and cultural threats to the local population but also can be seen as driver for further pressure on scarce resources and environment degradation $[8,17]$. However, it is important to note that while land degradation is sometimes accompanied by population growth, land restoration and improvement may also occur under such conditions [19]. Brou [8] has showed through a multivariate statistical study that wet forest reserves have played an important role in the spatial mobility of the population in Côte d'Ivoire. Land use change can be seen as a cause of environment degradation, but, it can also be interpreted as a consequence of stresses such as negative rainfall trends, inadequate agricultural policies and the need to increase production to accommodate population growth [5].

\subsubsection{Rainfall Dynamics}

Analysis of rainfall trends is a key element in the assessment of climate variability in this region. The comparative analysis of the two precipitation input data sets revealed large differences both in space and in time within in this region on the three decade period. To understand the impact of environmental degradation on local climate variability we study by Kriging, changing Isohyets by decade with data from thirteen stations (Figure 6). Isohyets vary globally between 2100 and $1000 \mathrm{~mm}$. From a decade to the other, high spatial variability isohyets were observed. There was a decrease of isohyets from Northwest to Southeast. Although the decade 1981-1990 (Figure 6(b)) was wetter, this trend is maintained. Isohyet $1200 \mathrm{~mm}$ taken as reference moves regularly to stabilize around Sassandra city (Figure 6(c)).

By examining the spatial evolution of isohyets, it appears the establishment of a corridor of dry zone NE-SW direction (Figure 6(c)). Sassandra area behaves as a microclimate under anthropogenic influence and marine variation. Reduced rainfall affects vegetation that will eventually disappear over time. Studying in Côte d'Ivoire Brou et al. [20] have linked the decline in rainfall with the beginning of the massive deforestation followed farming in the forest to the south of the country. Monteney [21] has showed that the forest ecosystem that borders the Gulf of Guinea recycles about $60 \%$ to $75 \%$ of annual rainfall; whereas annual crops that recycle $45 \%$ $55 \%$. We normally observe increasingly declining rainfall in this region. The annual rainfall shortage estimated for some countries in West Africa (Côte d'Ivoire, Burkina Faso, Mali, Senegal etc.) is $20 \%$ to $40 \%$ compared to the average interannual [22-24]. Rainfall trends and variability affect directly or indirectly various other variables, such as rainfed crop productivity, vegetation and soil degradation processes, reduction in the quality and quantity of ecosystems services, human livelihoods [6, 7].

A study of the impact of this reduction in rainfall and its spatial distribution was conducted in Gagnoa and Sassandra station (Figure 7). It shows that these changes affect hugely consecutive duration of wet periods in this region. More than four months in the 50s, there has been a period of two months on average for the first season in the 2000s. In the second season, the average is reduced to 


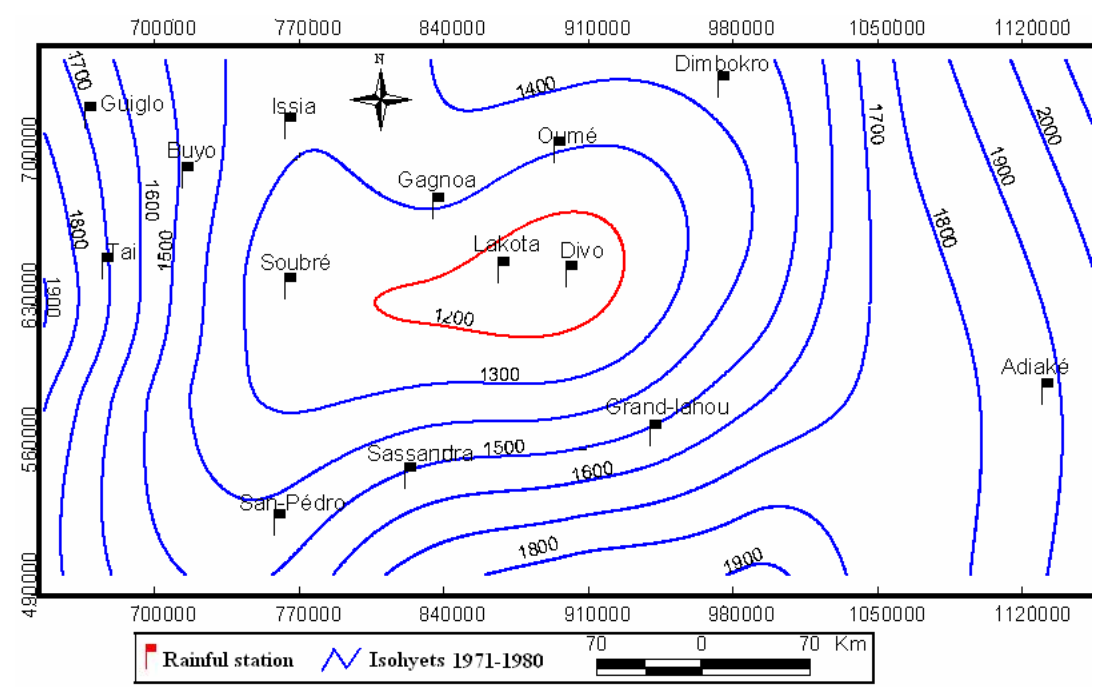

(a)

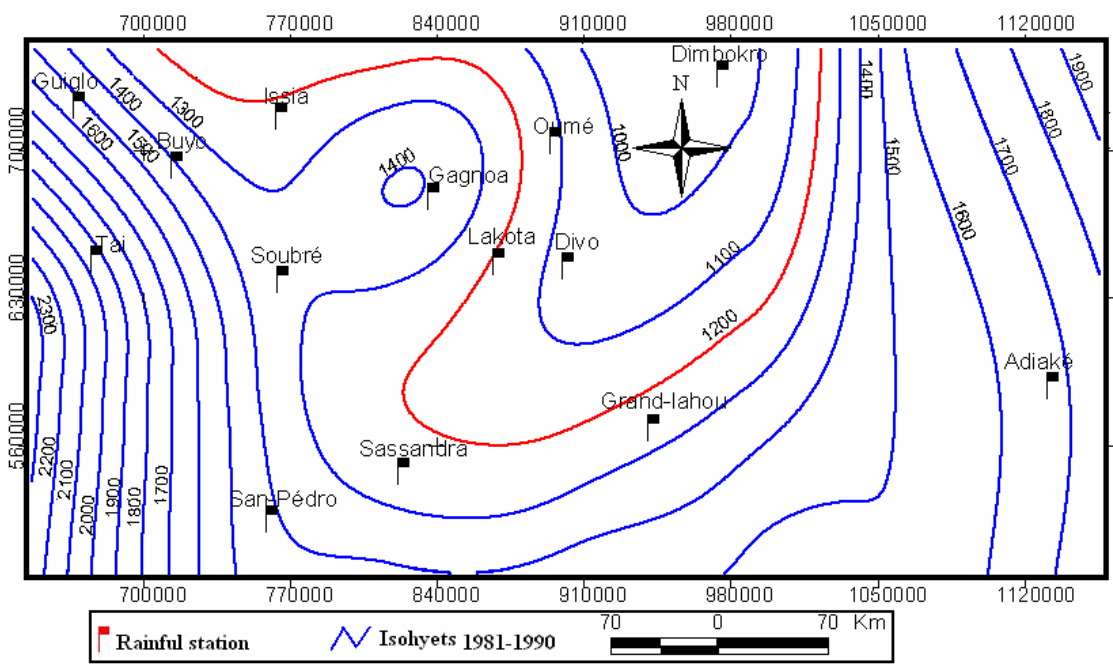

(b)

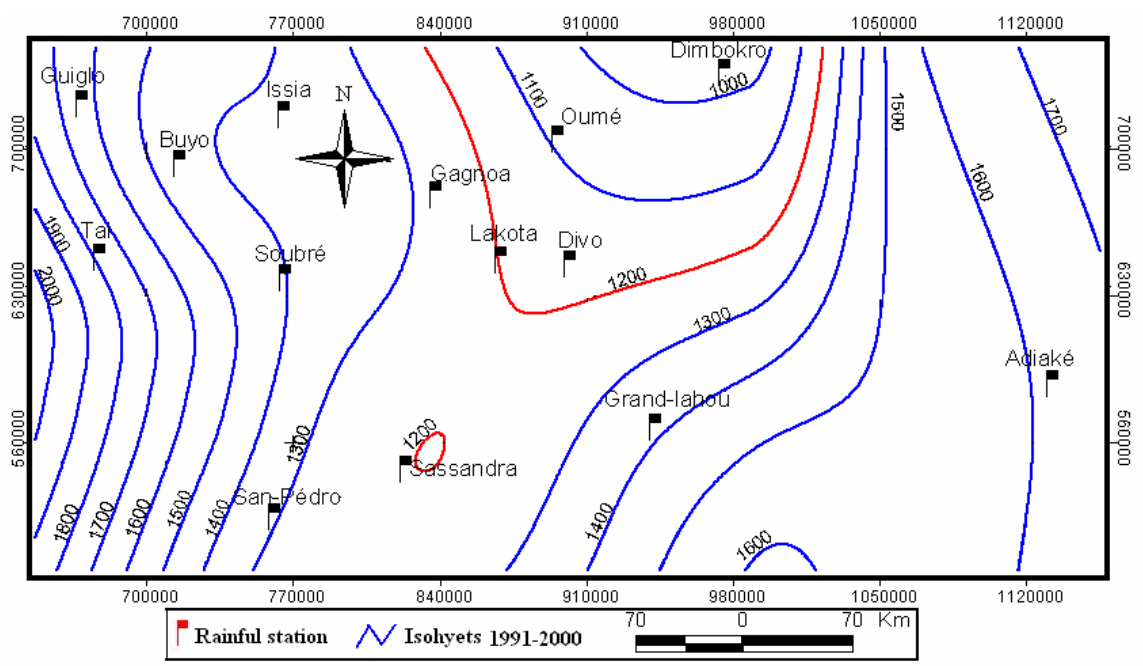

(c)

Figure 6. Evolution in time and space of isohyets of Sassandra station. a) Decade 1971-1980; b) decade 1981-1990; c) Decade 1991-2000. 
SASSANDRA in first season

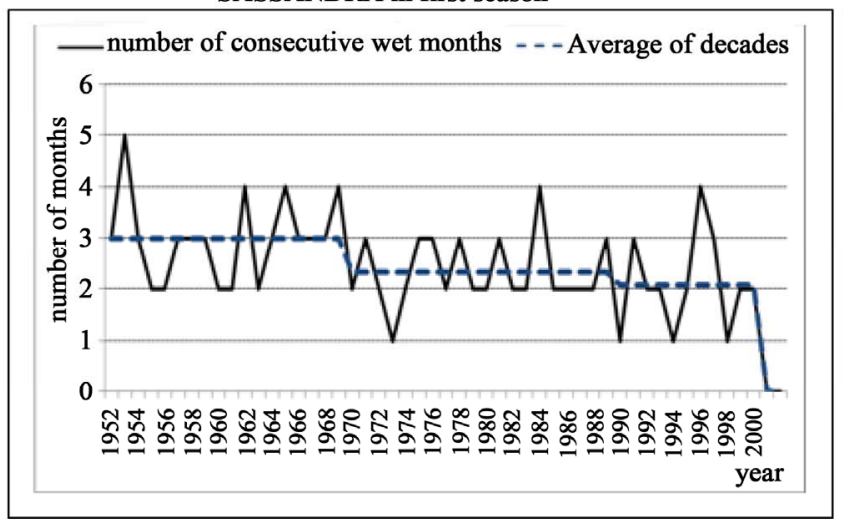

SASSANDRA in 2nd season

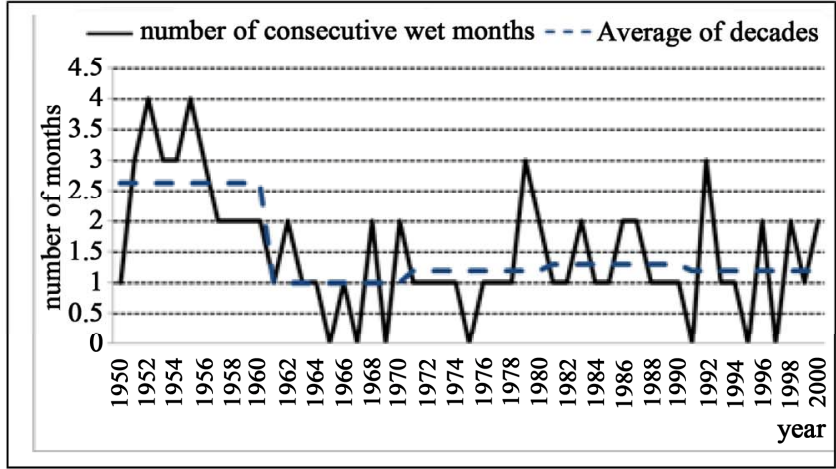

GAGNOA in first season

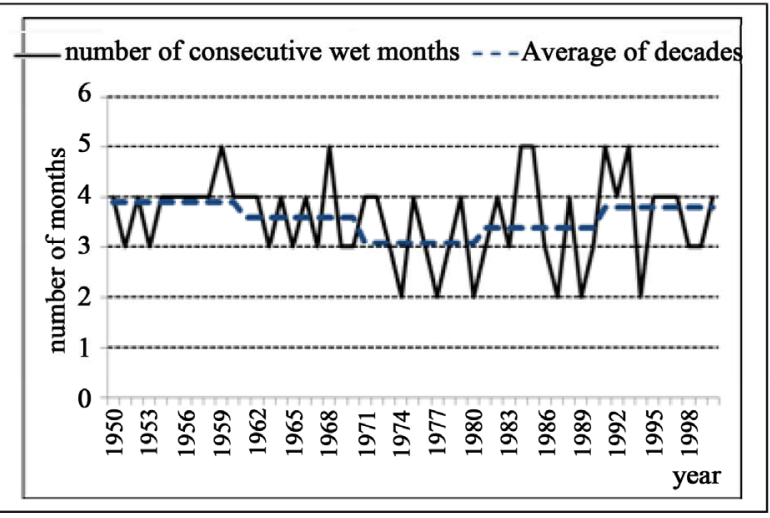

GAGNOA in 2nd season

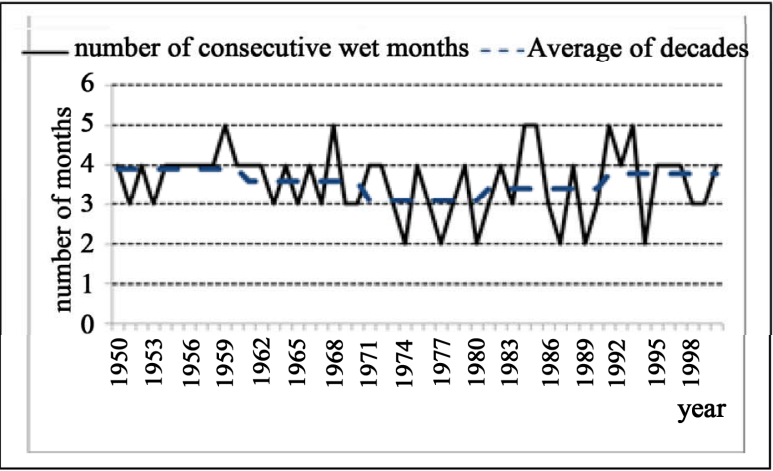

Figure 7. Number of consecutive months wet (rain $\geq$ ETP) in the first and second agricultural season in Gagnoa and Sassandra.

one month, particularly in the station Sassandra.

This situation will influence agricultural production in this region. The combination of climate variability, climate change, population growth (migration), an increase of arable land needs populations, forest clearing for new crops and uncontrolled management of natural resources seem to altering the balance nature of this region and amplify the vulnerability of soils $[5,17,25,26]$.

The analysis of climate risk in the agricultural is based on the example of the two stations: Gagnoa and Sassandra. The analysis of the Figure 8(a) indicates that at Gagnoa the first growing season began in the second decade of March and ends in the second decade of July, about four months in the period 1951-1970 as noted by Brou [8]. Figure 8(a) shows that the very wet phase (P $>=$ ETP) varies with time in the station Gagnoa. It is more than four months in the first growing season and reduced around three months in the second period from 1951 to 1970 . During the period 1970-2000, there was a reduction of these wet periods. At the Sassandra station (Figure 8(b)), wet periods are reduced respectively to three months in the first season and one months and half for the second season in the period 1951-1970. From 1970 to 2000 the first season is reduced to two and half months and the second in one month.
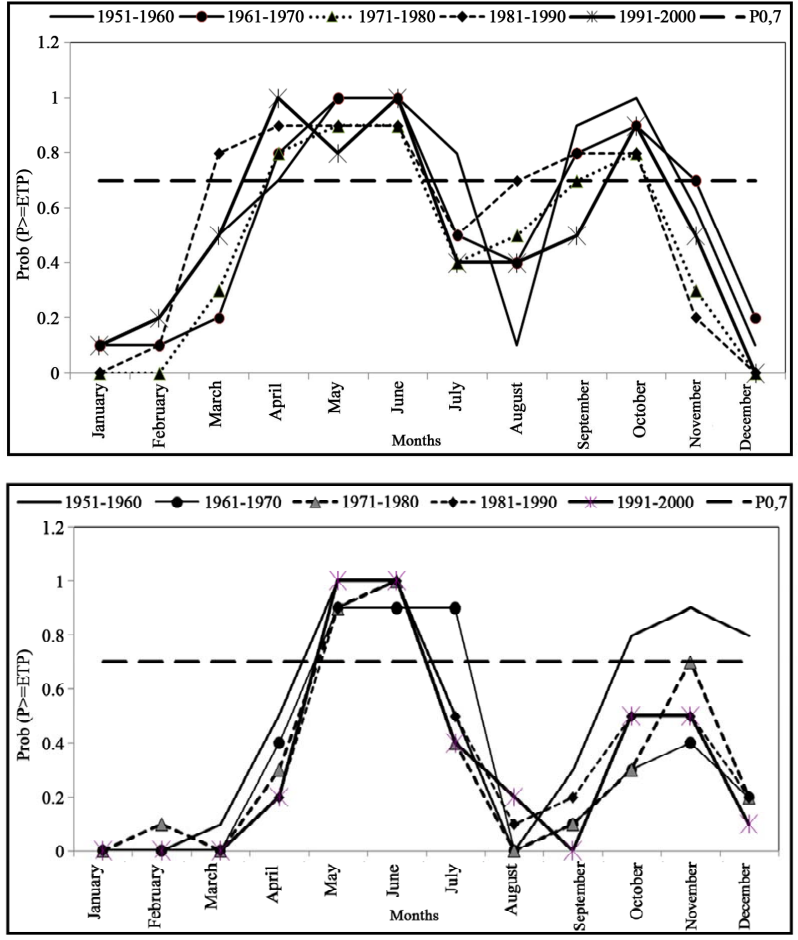

Figure 8. Variation in very wet periods at Gagnoa and Sassandra station. 
The choice of a probability (p), reflecting the risk of more or less complete loss of the crop due to water shortages, acceptable to the farmer, sets the corresponding period of rainfed. Rainfed agriculture is increasingly threatened in the southwest of Côte d'Ivoire. The probability is that a loss of crops every third month has become very high in the period 1970-2000, especially in the area of Sassandra.

Indeed, Brou [8] has shown that, in a study of the variability of growing seasons in the period 1970-1996, the second growing season debuted 20 days later. This situation can have redhibitory effects on the crop. In the context of reducing the growing season, the risk of crop loss is becoming increasingly important for rained crop whose cycles extend beyond 100 days. The risk also exists for perennial crops since the water needs are less satisfied during the flowering period (May and June) [8]. Crop vulnerability is accentuated by the reduction of forest, agricultural land subject to agricultural strong population pressure. Moreover, Panahi et al. [27] has shown in their study that the intensity of the peak floods has increased, while the agricultural lands showed increase in the basin. One of the key factors influencing the susceptibility of a region to soil erosion is land cover [28].

Indeed, Environmental degradation is a complex issue linked to much more than climate change and variability. If political, social and economic aspects are dismissed in the analysis an incomplete picture of current and historical changes is obtained according to Mbow et al. [5]. This environmental change may be caused internal as well as external factors. Environmental change in the study area over the last decades may be regarded as "land degradation" defined as a reduction in the biological or economic productivity of the land caused by a range of processes including rainfall reduction, soil nutrient depletion of croplands, overuse of natural vegetation which, in turn, may have caused such as increasing population pressure. All these factors act directly as well as indirectly and interact with each other. In fact, it's known that, due to the large surface area of their canopies, forests have an important impact on hydrological processes at the atmosphere-land interface [29-31]. Earlier research on environmental and land use change has been based on an analytical framework which places peoples livelihoods at the center $[32,33]$. This paper tries to demonstrate the high complexity of the rural "system", including the bio-physical changes, the internal and external drivers of change.

\section{Conclusion}

Using remote sensing based on land cover change analysis, climatic data, national statistical data; we analyzed the drivers of environmental change in the Southwestern of Côte d'Ivoire. With Geographic Information System analytical tools, the present study enables to monitor spatial and temporal land cover changes in Sassandra region. This study was conducted using two Landsat Thematic Mapper (TM) images acquired in the years 1986 and 2001, climatic data in the years 1950 to 2000 at Gagnoa and Sassandra station. Demographic data concern statistical yearbooks of General Census of Population and Housing in 1988 and 1998.

The structural changes in the agricultural sector observed since independence of Côte d'Ivoire (1960) have been imposed by several new challenges such as the rainfall decline since 1970s and local socio-economic factors. The agricultural development outlined has taken place, in this region, with little concern for ecological factors. Thus, observed environmental trends in southwestern Côte d'Ivoire are results of a set of partly interrelated human and natural factors. Changing in climatic and environmental conditions observed during the last three decades was accompanied by a significant spatial mobility of rural populations. The pressure exerted by these populations on forest resources, leads to inevitable changes in Ivorian forest. Consequently, Adapted strategies for forest management are necessary to mitigate adverse effects of climate change.

\section{Acknowledgements}

Direction of National Meteorology of Côte d'Ivoire is gratefully acknowledged for providing the data rainfall.

\section{REFERENCES}

[1] FAO, "Etat des Ressources Phytogénétiques Pour l'Alimentation et l'Agriculture: Second Rapport," République de Côte d'Ivoire, 2009.

[2] R. Zaki, A. Zaki and S. Ahmed, "Land Use and Land Cover Changes in Arid Region: The Case New Urbanized Zone, Northeast Cairo, Egypt," Journal of Geographic Information System, Vol. 3, No. 3, 2011, pp. 173-194. http://dx.doi.org/10.4236/jgis.2011.33015

[3] G. Mahé and Y. L'Hote, “Analysis of a Sahelian Annual Rainfall Index from 1986 to 2000; the Drought Continues," Hydrological Sciences Journal, Vol. 47, No. 4, 2002, pp. 563-495. http://dx.doi.org/10.1080/02626660209492960

[4] G. Mahé and Y. L'Hote Sahel, "Une Sécheresse Persistante et un Environnement Profondément Modifié," La Météorologie No 44 Revue de la Société Météorologique de France, 2004, pp. 2-3.

[5] C. Mbow, O. Mertz, A. Diouf, K. Rasmussen and A. Reenberg, "The Histoty of Environment Change and Adaptation in Eastern Saloum-Senegal-Driving Forces and Perceptions," Global and Planetary Change, Vol. 64, No. 3-4, 2008, pp. 216-221. http://dx.doi.org/10.1016/j.gloplacha.2008.09.008

[6] M. Boko, I. Niang, A. Nyong, C. Vogel, A. Githeko, M. 
Medany, B. Osman-Elasha, R. Tabo, P. Yanda, "Africa," In: M. L. Parry, O. F. Canziani, J. P. Palutikof, P. J. van der Linden, C. E. Hanson, Eds., Climate Change 2007: Impacts, Adaptation and Vulnerability. Contribution of Working Group II to the Fourth Assessment Report of the Intergovernmental Panel on Climate Change, Cambridge University Press, Cambridge, pp. 433-467.

[7] Millennium Ecosystem Assessment, "Ecosystems and $\mathrm{Hu}-$ man Well-Being: Biodiversity Synthesis," World Resources Institute, Washington DC, 2005.

[8] Y. T. Brou, "Risques Climatiques, Pressions Foncières et Agriculture en Côte d'Ivoire," Global Change: Facing Risks and Threats to Water Resources, Proceedings of the 6th World FRIEND Conference, Fez, October 2010.

[9] G. C. Nelson, E. Bennett, A. A. Berhe, K. Cassman, R. DeFries, T. Dietz, A. Dobermann, A. Dobson, A. Janetos, M. Levy, D. Marco, N. Nakicenovic, B. O’Neill, R. Norgaard, G. Petschel-Held, D. Ojima, P. Pingali, R. Watson and M. Zurek, "Anthropogenic Drivers of Ecosystem Change: An Overview," Ecology and Society, 2006.

[10] P. Serra, X. Pons and D. Sauri, "Land-Cover and LandUse Change in a Mediterranean Landscape: A Spatial Analysis of Driving Forces Integrating Biophysical and Human Factors," Applied Geography, Vol. 28, No. 3, 2008, pp. 189-209. http://dx.doi.org/10.1016/j.apgeog.2008.02.001

[11] J. M. Avenard, M. Eldin, G. Girard, J. Sircoulon, P. Touchebeuf, J. L. Guillaumet, E. Adjanohoun and A. Perraud, "Le Milieu Naturel de la Côte d'Ivoire," Mémoire ORSTOM, Paris, 1971.

[12] A. K. Jain, M. N. Murty and P. J. Flynn, "Data Clustering," ACM Computing Surveys, Vol. 31, No. 3, 1999, pp. 264-323. http://dx.doi.org/10.1145/331499.331504

[13] M. Eldin, "Risques Climatiques, Eléments des Risques Encourus Pour la Production Agricole. Dynamiques des Systèmes Agraires," ORSTOM, Collection et Séminaires, Paris, 1985, pp. 232-238.

[14] P. Franquin, "Analyse Agroalimentaire en Régions Tropicales: Méthodes des Intersections et Période Fréquentielle de la Végétation," L'Agronomie Tropicale, Vol. 28, 1973, pp. 6-7.

[15] Ndabalisye, "Agriculture Vivrière Ouest-Africaine à Travers le cas de la Côte d'Ivoire," Monographie, Institut des Savanes, Bouaké, 1995.

[16] J. Nyssen, J. Poesen and J. Deckers, "Land Degradation and Soil and Water Conservation in Tropical Highlands," Soil and Tillage Research, Vol. 103, No. 2, 2008, pp. 197-202. http://dx.doi.org/10.1016/j.still.2008.08.002

[17] G. J. Ibo, "Retraits de Terre sur les Fronts Pionniers du Grand Ouest Ivoirien. Eléments d'Une Approche SocioHistorique," J. des Sciences Sociales, 2008, pp. 7-32.

[18] A. Spiess, "Developing Adaptive Capacity for Responding to Environmental Change in the Arab Gulf States: Uncertainties to Linking Ecosystem Conservation, Sustainable Development and Society in Authoritarian Rentier Economies," Global and Planetary Change, Vol. 64, No. 3-4, 2008, pp. 244-252. http://dx.doi.org/10.1016/j.gloplacha.2008.10.008

[19] M. Tiffen, M. Mortimore and F. Gichuki, "More People, Less Erosion: Environmental Recovery in Kenya," John Wiley \& Sons, Chichester, 1994.

[20] T. Y. Brou, E. Servat and J. E. Paturel, "Contribution à l'Analyse des Interrelations Entre Activités Humaines et Variabilité Climatique: Cas du sud Forestier Ivoirien," Académie des Sciences/Elsevier, Paris, 1998.

[21] B. A. Monteny, “Contribution à l'Etude des Interactions Végétation-Atmosphère en Milieu Tropicale Humide. Importance du Rôle du Système Forestier Dans le Recyclage des Eaux de Pluies," Thèse de Doctorat d'Etat, Université de Paris-Sud Centre d'Orsay, 1987.

[22] A. Dai, P. J. Lamb, K. E. Trenberth, M. Hulme, P. D. Jones and P. Xie, "The Recent Sahel Drought Is Real," International Journal of Climatology, Vol. 24, No. 11, 2004, pp. 1323-1331. http://dx.doi.org/10.1002/joc.1083

[23] J. E. Paturel, M. Ouedraogo, E. Servat, G. Mahé, A. Dezetter and J. F. Boyer, "The Concept of Rainfall and Streamflow Normals in West and Central in Context of Climatic Variability," Hydrological Sciences Journal, Vol. 48, No. 1, 2004, pp. 125-137. http://dx.doi.org/10.1623/hysj.48.1.125.43479

[24] B. T. A. Goula, F. W. Kouassi, V. Fadika, K. E. Kouakou, G. B. Kouadio, K. Koffi, K. Bamory, I. Doumouya and I. Savané, "Impacts du Changement et de la Variabilité Climatiques sur les Eaux Souterraines en Zone Tropicale Humide: Cas de la Côte d'Ivoire," IASH Publication, Vol. 334, 2009, pp. 190-202.

[25] K. J. Wessels, S. D. Prince, J. Malherbe, J. Small, P. E. Frost and D. Vanzyl, "Can Human-Induced Land Degradation Be Distinguished from the Effects Rainfall Variability? A Case Study in South Africa," Journal of Arid Environments, Vol. 68, No. 2, 2007, pp. 271-297. http://dx.doi.org/10.1016/j.jaridenv.2006.05.015

[26] F. Rey, J. L. Ballais, A. Marre and G. Rovéra, "Rôle de la Végétation Dans la Protection Contre l'Erosion Hydrique de Surface," C. R. Geoscience, Vol. 336, 2004, pp. 991998. http://dx.doi.org/10.1016/j.crte.2004.03.012

[27] A. Panahi, B. Alijani and H. Mohammadi, "The Effect of the Land Use/Cover Changes on the Floods of the Madarsu Basin of Northeastern Iran," Journal of Water Resource and Protection, Vol. 2, No. 4, 2010, pp. 373-379. http://dx.doi.org/10.4236/jwarp.2010.24043

[28] T. Cebecauer and J. Hofierka, "The Consequences of Land-Cover Changes on Soil Erosion Distribution in Slovakia," Geomorphology, Vol. 98, No. 3-4, 2008, pp. 187 198.

[29] F. Gallart and P. Llorens, "Catchment Management under Environmental Change: Impact of Land Cover Change on Water Ressources," Water International, Vol. 28, No. 3, 2003, pp. 334-340. http://dx.doi.org/10.1080/02508060308691707

[30] P. Zhou, O. Luukkanen, T. Tokola and J. Nieminen, "Effect of Vetation Cover on Soil Erosion in a Mountainous Watershed," Catena, Vol. 75, No. 3, 2008, pp. 319-325. http://dx.doi.org/10.1016/j.catena.2008.07.010

[31] D. Crawford-Brown, "Assessing the Sensitivity of Cli- 
mate Change Targets to Policies of Land Use, Energy Demand, Low Carbon Energy and Population Growth," Journal of Environmental Protection, Vol. 3, 2012, pp. 1615-1624. http://dx.doi.org/10.4236/jep.2012.312178

[32] G. G. Tappan, M. Sall, E. C. Wood and M. Cushing, "Ecoregions and Land Cover Trends in Senegal," Journal of Arid Environments Vol. 59, No. 3, 2004, pp. 427-462. http://dx.doi.org/10.1016/j.jaridenv.2004.03.018

[33] E. C. Wood, G. G. Tappan and A. Hadj, "Understanding the Drivers of Agricultural Land Use Change in SouthCentral Senegal," Journal of Arid Environments, Vol. 59, No. 3, 2004, pp. 565-582.

http://dx.doi.org/10.1016/j.jaridenv.2004.03.022 